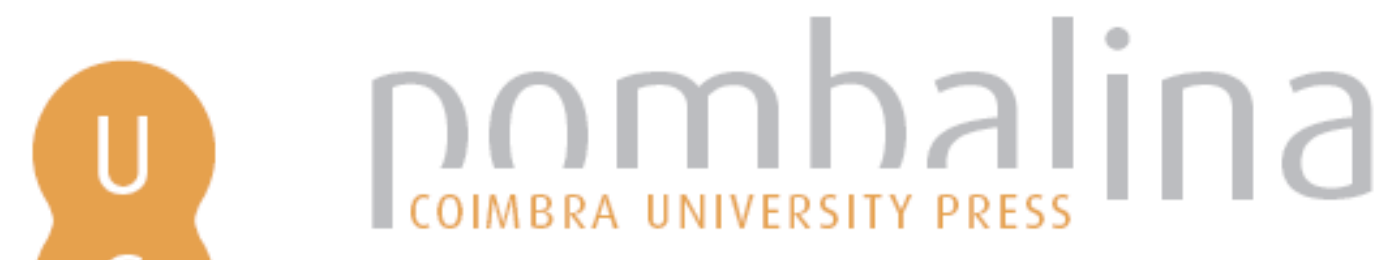

\title{
Sound/unsound: teaching/not teaching: the sounds of English
}

Autor(es): $\quad$ Silver, Diana

Publicado por: Imprensa da Universidade de Coimbra

URL

persistente: URI:http://hdl.handle.net/10316.2/35925

DOI: $\quad$ DOI:http://dx.doi.org/10.14195/978-989-26-0690-3_12

Accessed : $\quad$ 26-Apr-2023 12:50:46

A navegação consulta e descarregamento dos títulos inseridos nas Bibliotecas Digitais UC Digitalis, UC Pombalina e UC Impactum, pressupõem a aceitação plena e sem reservas dos Termos e Condições de Uso destas Bibliotecas Digitais, disponíveis em https://digitalis.uc.pt/pt-pt/termos.

Conforme exposto nos referidos Termos e Condições de Uso, o descarregamento de títulos de acesso restrito requer uma licença válida de autorização devendo o utilizador aceder ao(s) documento(s) a partir de um endereço de IP da instituição detentora da supramencionada licença.

Ao utilizador é apenas permitido o descarregamento para uso pessoal, pelo que o emprego do(s) título(s) descarregado(s) para outro fim, designadamente comercial, carece de autorização do respetivo autor ou editor da obra.

Na medida em que todas as obras da UC Digitalis se encontram protegidas pelo Código do Direito de Autor e Direitos Conexos e demais legislação aplicável, toda a cópia, parcial ou total, deste documento, nos casos em que é legalmente admitida, deverá conter ou fazer-se acompanhar por este aviso.

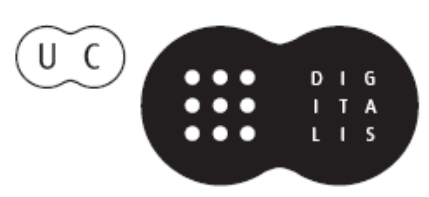




\section{O CRUZAMENTO DE SABERES NA AULA DE INGLÊS}

CONTRIBUTOS PARA UMA PRÁTICA MULTIDISCIPLINAR

ANA R. LUÍS COORD.

IMPRENSA DA UNIVERSIDADE DE COIMBRA COIMBRA UNIVERSITY PRESS 
SOUND/UNSOUND: TEACHING/NOT TEACHING

THE SOUNDS OF ENGLISH

\section{Diana Silver}

The question that simply will not go away is this: Can pronunciation be taught?

SCOTT THORNBURY (2010)

\section{Introduction}

"The problem is, they don't know how to say the words." Sandra, a teacher of $7^{\text {th }}$ grade students, is describing her class. They listen to a song about possible jobs, then answer the teacher's comprehension questions. Or rather, they don't answer, or are barely understandable when they do, because they have no confidence in saying even a single item like 'baker', let alone putting it into a well-inflected utterance. The problem here seems to be not so much comprehension, or content, as phonology.

Given this situation, the question "Is teaching pronunciation necessary, desirable or even possible?" seems otiose. Nevertheless, the controversy has rumbled on for decades among ELT professionals. Scott Thornbury (2010) has called it "the question that will not go away", with his avowed scepticism arousing a storm of correspondence, for and against, on his blog. The present article firstly examines some recent views on teaching pronunciation, highlighting the intensely personal nature of the skill. We go on to look at what is happening currently in Portuguese state and private schools, at elementary and secondary level, through the results of a small local survey of teachers in the Central region. The question of the language variety to choose as a model is clearly controversial. The hegemony of 'first circle' standard varieties is now seen as an example 
of cultural and linguistic imperialism, with both outer circle and 'global' Englishes presented as alternatives for international communication. I look at some of the options, including the pronunciation of English as a Lingua Franca, and discuss the relative importance of prosodic features such as intonation and stress in this model.

Finally, since coursebooks and syllabuses in use in Portuguese schools largely neglect pronunciation in general and prosodic features in particular, I end with some suggestions for the observation and practice of prosodic features, this being an area which teachers agree is important, which can only gain in importance with the wider use of speaking assessment in schools, and which will obviously repay creative attention and energy devoted to it in the classroom by both teachers and students.

\section{2. 'Spending the time on more important stuff': recent controver- sies on the value of pronunciation teaching}

That pronunciation has been a neglected area of English teaching, in native-speaking and non-native speaking countries, is well recognised (Rogerson-Revell 2011:5). Cruttenden (2008:315) blames the neglect on the predominance of grammar in teaching and on the increased use of English for international communication. The neglect seems surprising, however, given the results of Jenkins' research (2000), which point to the "almost negligible role of incorrect grammar as cause of miscommunication. This is in marked contrast with the importance most coursebooks give to grammar, and the amount of class time most of us as teachers dedicate to this area" (Walker 2010:26).

But is this neglect of pronunciation in any way justifiable? - is it to some extent a natural and inevitable state of affairs, or is it something that needs to be remedied? Recently this 'question that simply will not go away' was raised in typically lively style in Scott Thornbury's blog $A n$

$A-Z$ of ELT (posted 1/8/2010). Thornbury is sceptical about the value of pronunciation teaching ("As a teacher, I have to confess that I can't recall any enduring effects for teaching pronunciation in class"), while admitting 
that what pronunciation teaching he has done is mostly reactive ("a case of responding to learners' mispronunciations with either real or feigned incomprehension" - a perfectly valid technique, incidentally, which most teachers will recognise and employ). After referring to research findings supporting his scepticism, however, he remains unsure about how to react:

Now, is this bad news (we can't do much to help our learners achieve acceptable standards of pronunciation)? Or is it good news (we don't have to teach pronunciation, and can spend the time saved on more important stuff)?

As expected, Thornbury's blog aroused plenty of controversy (59 responses) among teachers and some researchers worldwide. Some, including the eminent Stephen Krashen, referring to his own paper (Krashen 1997), strongly agree with Thornbury, but there are considerably more, including several teachers from Brazil, who argue eloquently in favour of a focus on pronunciation. One correspondent, Ronaldo (Thornbury 2010), remarks that these opinions tend to divide along NES (native English speaker)/ NNES (non-native English speaker) lines, with the NNES teachers being generally more favourable to pronunciation teaching (on this, compare my own small-scale local findings, section 2 below).

Comments in the blog favourable to pronunciation teaching concentrate on the potentially lethal results of errors (in air-traffic control), on the motivating effects of 'good' pronunciation as shown by successful oral communication, on the usefulness of NNES teachers (who can give informed feedback on those learners' errors which show L1 influence see Seidlhofer 1999:235), on pronunciation software now available with coursebooks, on the need for focus on suprasegmental features, and above all on the necessity of linking pronunciation with listening activities. On the other hand, many of the less favourable comments focus on difficulties, reminding us of the intimate nature of pronunciation. ALiCe_M writes (Thornbury 2010) that "correcting the sounds somehow feels more personal than correcting a grammar error". Krashen (1997) conjectures in his paper, on what he admits is "flimsy evidence", that 
"accurate pronunciation in a second language, even in adults, is acquired rapidly and very well. We simply do not use our best accents because we feel silly", since the output filter, "a block that keeps us from doing our best ... prevents us from using what we have acquired". According to him, "there is no evidence that second language accent can be improved by direct instruction". (This view is unsurprising, given Krashen's theory of language acquisition [1986:62, in Brown 2007], whereby all that is necessary for acquisition of an L2 is comprehensible input - direct instruction, whether of grammar or any other aspect of language, being unnecessary).

Thornbury (2010:5) himself clarifies and qualifies his original statements, emphasising learners' rather than teacher's difficulties, stressing, as do correspondents, the need to link pronunciation to listening, and agreeing that sound-spelling relationships are worthy of attention. However,

(...) random, segregated activities that focus on the three pronunciations of the past simple inflection (-ed) - well, I'm not so sure. Teachers may teach these "pronunciation macnuggets", but what evidence do we have that learners learn them? (4)

Furthermore, the usual awareness-raising activities that teachers use to highlight grammatical and lexical features do not work with pronunciation; for Thornbury, it is very difficult to get students to perceive and produce 'foreign', non-L1 phonemes in natural speech, "just as you can 'raise my awareness' that there are sounds that a bat can hear but that I can't, though it won't make me hear them" (7). For him, the only useful thing a teacher can do in class is to indicate when a learner's pronunciation is unintelligible (9). This immediately produced a query from Natalia (10) about phonological accommodation in L1-homogenous groups, constantly exposed to and using the same L1-influenced pronunciation: "considering that intelligibility is as much a feature of the listener as it is of the speaker, how could we expect to use communication breakdown as a motivation to teach pronunciation?" This is indeed a problem which many of us will have encountered: if learners are getting involved in an interesting communicative activity in L2, they will use either L1, or 
if sufficiently motivated, L2 - but possibly in the form of a semi-fluent classroom pidgin, a variety which may be incomprehensible to outsiders or foreigners. Thornbury's answer to Natalia is for the teacher to 'play dumb', to bring in English-speaking outsiders to the class, and to encourage students to interact with foreign speakers outside the classroom.

Though this flurry of interest among teachers arose relatively recently, doubts about the utility of pronunciation teaching are hardly new. Setter \& Jenkins (2005), in their survey article, found that pronunciation has been "universally considered to be a 'difficult' aspect of an L2 to teach, probably the most difficult" (1). This may be because L1 pronunciation habits are formed early. A group of Australian teachers found that

by far the majority of pronunciation problems stem not from physical, articulatory causes, but from cognitive causes. (...) Learners need to 'unlearn' the concepts they have held since babyhood for (...) sounds, and replace them with the similar but different concepts needed to speak English. (Teaching pronunciation 2001:20)

Furthermore, pronunciation projects our social and ethnic identity; L2 learners may therefore be "subconsciously resistant to change, despite superficially wanting a 'native-like' accent". A major problem, they found, was the subconscious level at which pronunciation, particularly suprasegmental features, operates, which makes it difficult to work on (2). They quote Daniels (1997:82), who gives a powerful image of this resistance to "the development of a new ego", presenting our accents as:

a sort of umbilical cord which ties us to our mother. Whenever we speak an L2 we cut that cord, perhaps unconsciously afraid of not being able to tie it up again when we revert to L1... A possible way of avoiding the cut is to continue using the sounds, the rhythm and the intonation of our mother tongue while pretending to speak L2.

Most teachers will have experienced such resistance, particularly perhaps on the part of teenage boys anxious about their emerging adult 
selves. As Walker says (2010:66), "adolescents are often struggling to define their own mother-tongue identity, especially in front of their peers. This would not appear to be the best moment to ask them to take on a new identity through pronunciation". Could the comparative confidence of many young teenage girl students in producing L2 sounds, which some teachers have noticed, reflect their relative confidence in their own identity, and a corresponding willingness to 'try on' other identities as presented in the sounds of a language? Walker's emphasis (2010:65) on teaching 'Lingua Franca Core' pronunciation as a way of circumventing such identity issues will be mentioned in section 4 below.

\section{What we do - some indications of the present practice of pro- nunciation teaching in Portugal}

We have seen that whatever else they may disagree on, few dispute that teaching and learning pronunciation is difficult; what correspondents worldwide (many of them Brazilian) on Thornbury's (2010) blog say, is that they continue to do it, despite the difficulties. Is this determination also seen in Portugal? - what aspects of pronunciation are focused on, why, and how frequently? This section looks at the results of a small survey carried out in 2011/2012 in the Central region of Portugal by means of a questionnaire, respondents being 14 state-school teachers (Portuguese nationals, 13 NNES and 1 bilingual) and, for purposes of comparison, 7 language-school teachers (NES, British). While the state-school teachers were teaching mainly teenagers in $3 .^{\circ}$ ciclo and secondary schools, the age range and level of the language-school students was more diverse from young children and beginners to advanced levels, though here too adolescents and teenagers predominate. In addition to the questionnaire, I conducted informal interviews with 7 orientadoras from schools in the Central region (mentioned in footnotes 1, 2, 6, 7 and 9 below). Results of answers to the survey questions are tabulated below, with some comments on each set of data. 


\begin{tabular}{|l|c|c|}
\cline { 2 - 3 } \multicolumn{1}{c|}{} & \multicolumn{2}{c|}{ Number of replies } \\
\hline $\begin{array}{l}\text { How often do you spend any time in class on the } \\
\text { pronunciation of English? }\end{array}$ & $\begin{array}{c}\text { State school } \\
\text { (total 14) }\end{array}$ & $\begin{array}{c}\text { Language school } \\
\text { (total 7) }\end{array}$ \\
\hline At least once a week & $5^{1}$ & 6 \\
\hline Every 2 -3 weeks & 2 & 0 \\
\hline Once a month, approx. & 3 & 0 \\
\hline Rarely & 4 & 1 \\
\hline
\end{tabular}

The majority (62\%) of respondents deal with pronunciation in class on a regular basis, with language-school teachers tending to devote more time to it, but $38 \%$ do phonological work once a month or less.

TABLE 2

\begin{tabular}{|l|c|c|}
\cline { 2 - 3 } \multicolumn{1}{c|}{} & \multicolumn{2}{c|}{ Number of replies } \\
\hline $\begin{array}{l}\text { If 'once a month' or' rarely', choose 1 or 2 of the following: I } \\
\text { don't teach or practice pronunciation more often because - }\end{array}$ & $\begin{array}{c}\text { State school } \\
\text { (total 7) }\end{array}$ & $\begin{array}{c}\text { Language school } \\
\text { (total 1) }\end{array}$ \\
\hline students' pronunciation is good already & 3 & 1 \\
\hline uncertain what model to present & 3 & 0 \\
\hline too many other matters to deal with in class & 6 & 1 \\
\hline coursebooks don't deal with it & $5^{2}$ & 0 \\
\hline techniques are old-fashioned & 2 & 0 \\
\hline students uninterested & 0 & 0 \\
\hline
\end{tabular}

In Table 2, results show that curricular pressures and the lack of support from class materials, more than satisfaction with the state of students' pronunciation, are what deter teachers from devoting valuable

1 "We do a little every class", said one teacher when interviewed.

2 When interviewed, some teachers said they got most of their ideas and materials for pronunciation work from colleagues and other professional contacts, rather than from published materials. There was criticism of some CD material accompanying coursebooks, such as material being read in an unnatural way by Portuguese speakers. 
class time to pronunciation. The model of English to choose (British, American, 'global', etc.) is a problem for a minority.

TABLE 3

\begin{tabular}{|l|c|c|}
\cline { 2 - 3 } \multicolumn{1}{c|}{} & \multicolumn{2}{c|}{ Number of replies } \\
\hline $\begin{array}{l}\text { If 'weekly' or 'every 2 or 3 weeks', what areas of } \\
\text { pronunciation do you focus on? }\end{array}$ & $\begin{array}{c}\text { State school } \\
\text { (total 7) }\end{array}$ & $\begin{array}{c}\text { Language school } \\
\text { (total 6) }\end{array}$ \\
\hline Phonemes & 6 & 4 \\
\hline Prosodic features & 7 & 5 \\
\hline Linking sounds in connected speech & 4 & 4 \\
\hline Relation of sounds to written forms & 7 & 3 \\
\hline
\end{tabular}

It seems from the above that a very high percentage of teachers focus on suprasegmental features (namely those, e.g. intonation, that extend beyond single phonemes or syllables). Work on such features is not surprising, given the stress on the discourse contexts of pronunciation favoured in the communicative approach (Celse-Murcia, Brinton \& Goodwin 1996:10): there was a "dramatic swing" to prosodic features in the 1980s, a time when Strevens (1989:183, in Walker 2010:26) argued that "the suprasegmentals will carry the day because they bear the meaning of the message". Many teachers obviously realise that this is a necessary and agreeable area for class work, while not neglecting individual sounds. On the relation of sounds to written forms, see the comment on table 5 .

TABle 4

\begin{tabular}{|l|c|c|}
\cline { 2 - 3 } \multicolumn{1}{c|}{} & \multicolumn{2}{c|}{ Number of replies ${ }^{3}$} \\
\hline When you focus on pronunciation in class, are you: & $\begin{array}{c}\text { State school } \\
\text { (total 6) }\end{array}$ & $\begin{array}{c}\text { Language school } \\
\text { (total 3) }\end{array}$ \\
\hline usually responding to student errors (correcting)? & 6 & 2 \\
\hline often conducting activities planned in advance? & 3 & 2 \\
\hline
\end{tabular}

3 This question was not included in all questionnaires. 
Of those answering the above question, reactive teaching (signaling and correcting errors) rather than proactive teaching (pre-planning some deliberate focus on pronunciation, aiming to prevent errors happening) is clearly preferred, especially by state-school teachers. This difference may be due to the small classes and the wide range of materials available in language schools, as well as to the confidence that such teachers may have in their own ability to model pronunciation for their students. It must also be related to the prevalence of reading aloud with teacher correction, as recorded in Table 6 .

TABLE 5

\begin{tabular}{|l|c|c|}
\cline { 2 - 3 } \multicolumn{1}{c|}{} & \multicolumn{2}{c|}{ Number of replies } \\
\hline $\begin{array}{l}\text { What aspects of pronunciation do your students have } \\
\text { most problems with? }\end{array}$ & $\begin{array}{c}\text { State school } \\
\text { (total 14) }\end{array}$ & $\begin{array}{c}\text { Language school } \\
\text { (total 7) }\end{array}$ \\
\hline Recognising/ producing sounds & 7 & 3 \\
\hline Prosodic features & 10 & 5 \\
\hline Sound/ spelling relationship & 12 & 4 \\
\hline $\begin{array}{l}\text { Others (inserted) } \\
\text { - linking, weak forms }\end{array}$ & 0 & 1 \\
\hline
\end{tabular}

Table 5 shows that the lack of a close relationship between sound and spelling is seen as the major difficulty by these Portuguese English teachers. This is clearly related to the classroom activity preferred by this group, as shown in Table 6 below: they are aware of the problem and are therefore giving students practice in reading aloud. But might the activity itself be causing students to commit pronunciation errors, under the influence of the text which they see in front of them, errors which they might not make if they were not reading aloud but were speaking more freely, away from the malign influence of orthography? Certainly reading aloud, although a real-world skill in some contexts, has been criticised on a number of valid grounds (uncommunicative, lack of focus on meaning, often textually inappropriate, etc.). Indeed, it was

\footnotetext{
${ }^{4}$ Respondents were encouraged to add other aspects.
} 
firmly rejected by two respondents (see note 4). It remains popular, for both valid and more dubious reasons, however - we will look at it as a classroom technique in section 4 .

TABLE 6

\begin{tabular}{|c|c|c|}
\hline \multirow[b]{2}{*}{ How do (or would) you teach pronunciation? } & \multicolumn{2}{|c|}{ Number of replies } \\
\hline & $\begin{array}{l}\text { State school } \\
\text { (total 14) }\end{array}$ & $\begin{array}{l}\text { Language school } \\
\text { (total 7) }\end{array}$ \\
\hline Students read aloud, teacher corrects & 12 & $3^{5}$ \\
\hline Teacher models pronunciation & 6 & 6 \\
\hline Recorded voices used as models & 7 & 3 \\
\hline Listening to identify sounds, intonation, etc. & $8^{6}$ & 4 \\
\hline Drilling of individual sounds & 8 & 5 \\
\hline Drilling of word groups & $11^{7}$ & 6 \\
\hline Practicing songs, raps or chants & 10 & 5 \\
\hline Performing dialogues or plays & 8 & 4 \\
\hline $\begin{array}{l}\text { Others (inserted) }{ }^{8}: \\
\text { - computer program }\end{array}$ & 0 & 1 \\
\hline - use of phonemic script & 0 & 2 \\
\hline - students recording themselves & 0 & 1 \\
\hline - practice with tongue-twisters & 0 & 1 \\
\hline - various pronunciation games & 0 & 1 \\
\hline - dictation & 1 & 0 \\
\hline - focus on $\mathrm{L} 1 / \mathrm{L} 2$ contrasts & 1 & 0 \\
\hline
\end{tabular}

5 Two language school teachers vehemently rejected this activity ("Never". "I don't see the point of it"). Another said that she sometimes encouraged pairs to correct each other's reading.

${ }^{6}$ All the teachers interviewed agreed that detailed listening practice was essential in teaching pronunciation.

7 "Drilling them to death", as one teacher put it when interviewed, though such intensity seems rare.

8 Respondents were encouraged to add other methods/activities. 
Table 6 shows a pleasing diversity of methods. Notable is the continuing use of repetition techniques, popular in the Audiolingualism of the mid- $20^{\text {th }}$ century, and fortunately not rejected with the advent of the communicative approach.

In contrast with the views of certain writers on ELT, therefore, this small study indicates that teachers in Portuguese classrooms do not need convincing of the value of pronunciation teaching. For what is the alternative - to let errors pass unnoticed? Rather, many teachers try to teach reactively or proactively, in an attempt to avoid fossilisation. They also tend to agree with native-speaker teachers and researchers, that prosodic features such as intonation and stress are those which need most attention. The question of what variety to teach, though not seen by most as a major problem, will be considered briefly in the next section.

From the informal interviews with the orientadoras, mentioned above and in several footnotes, responses indicate that, while giving time and attention to oral production, these teachers focus more on speaking skills in general rather than pronunciation. (Asked about the main reasons for their students' difficulties or reluctance in speaking, they attributed this partly to lack of confidence with pronunciation, but also to lack of vocabulary). They now give increasing prominence to oral assessment, particularly since the Ministry of Education set up its development project in 2004/5 and ran a training programme for test writers and assessors between 2006 and 2009, culminating in the introduction of speaking tests for the $11^{\text {th }}$ and $12^{\text {th }}$ years of secondary school, with materials and precise instructions for interlocutors and scales to guide assessors (Gabinete de Avaliação Educacional). Although pronunciation plays a part in these assessment scales, it is given no separate criterion to itself, unlike in the international exams of Cambridge ESOL, for example. The reasons why such a criterion was rejected are unclear; might they be related to an assumption, on the part of the creators of the scales, that many Portuguese students would score highly on such a criterion - in other words, their "pronunciation is good enough already"? - an opinion rejected by most teachers in the present survey, as we have seen. However this may be, pronunciation is mentioned, quite briefly and in terms 
of comprehensibility, in the scale for Accuracy (Correção) - 15\% of the total, and in terms of speed and hesitation under Fluência - 10\%. The relatively small amount of time spent by teachers on pronunciation in class may be a washback effect of this relative lack of weight given to pronunciation in the official speaking tests.

\section{What pronunciation to teach - a brief world tour of available options}

Intelligibility is one of the three main goals of teaching International English, or English as a Lingua Franca pronunciation (Walker 2010:20), together with identity ("learners should be able to maintain their identity through their accents" - see section 1) and (fortunately) teachability (some aspects of pronunciation lend themselves more to classroom teaching than others, which may indeed better be left to be 'picked up'). What, however, is intelligibility? McKay (2002:52-53) defines three elements: intelligibility itself (simply recognising a word or expression), comprehensibility (knowing the meaning) and interpretability ("knowing what the expression signifies in a particular sociocultural context"); clearly, all three are important for communication. We must not forget, however, the crucial role of the listener (see section 1 in the context of L1-homogenous encounters) - what is easily intelligible between classmates in Portugal may not be so when they are on an exchange with a group of, say, Italian or Czech students.

Considering the model to be offered to our students, the time should surely be long gone, at least in Europe, when the native speaker of English was automatically placed in a privileged position as a teacher of the language, even if lacking any formal qualifications in language analysis or pedagogy. Kirkpatrick (2007:186-188) summarises the many arguments for the multilingual local teacher as against the monolingual NES teacher' (their experience as learners of English and probably

\footnotetext{
9 This common binary opposition NNES/NES may be simplistic, however, given the gradations of bilingualism in NNES teachers, and the fact that many NES teachers are, or become, at least moderately fluent in the L1 of the country.
} 
other languages, leading to greater respect from and empathy with their students, etc. - apart from their obvious availability). For Seidlhofer (1999:235), they are 'double agents', "facilitating learning by mediating between the different languages and cultures through appropriate pedagogy", while for Jenkins (2000:223-224) two crucial advantages are their ability to assess pronunciation from an L2 listener's perspective, and the fact that they are in a position to "take careful account of the link between L1 and identity, so enabling their learners to preserve their L1 identities in L2".

According to Cruttenden (2008:315), "there has been a sort of implicit assumption that the standard [of pronunciation] will be set by the teacher ... (combined with what the learner picks up from watching English or American TV and film) and that learners will simply pick up their pronunciation". Despite their manifest qualities, most NNES teachers are unlikely to have acquired NES pronunciation, and requiring them to reach, and teach, Received Pronunciation (RP - now anyway changing considerably, according to Trudgill 2002, in Collins \& Mees 2009:268), or General American (GA), or indeed any other of Kachru's Inner Circle standards (Kachru 1992), is not only a tall order, but unnecessary or even damaging to both teachers and students. Cook (2002:331, in Kirkpatrick 2007: 188) acknowledges the "impossible target" of attaining native-speaker pronunciation. According to Kirkpatrick:

It is hard to conceive of any other field in which the learners are implicitly informed that, not only can they never achieve the goal that the curriculum has set for them, but that this goal is even beyond their own teachers. Students who are continually evaluated against unrealistic, unattainable and inappropriate models will soon become disheartened and disillusioned (2007:188).

Just as, according to Widdowson (2003:43) "the very fact that English is an international language means that no nation can have custody over it", so requiring learners to attempt mastery of a more or less geographically and phonologically distant national variety is a throwback to the days of linguistic imperialism which can no longer be valid at a time when 
access to global media brings learners into contact with a dazzling range of cultural and phonological temptations and opportunities.

There will always be some learners whose future plans, past history or personal quirks lead them to a preference for, say, British or American pronunciation. For example, a marked desire by students for native-speaker rather than local pronunciation of English was reported from Austria by Dalton-Puffer et al. (1997, in McKay 2002:70). For the majority of students, however, practical considerations (pedagogic necessity or present and future usefulness) mean that another variety or varieties will be the target. The question is, what should this/these be? The choices seem to be as follows: a local variety (not relevant in non-Anglophone European countries, where no local varieties of English have developed); what Cruttenden (2008:10) has called Amalgam; and some form of International English, such as Jenkins' (2000) English as a Lingua Franca (EFL).

Amalgam English is defined by Cruttenden (2008:317) as a "hybrid between British and American varieties and possibly [native-speaker] varieties from the southern hemisphere and the Caribbean as well; additionally it will probably include a number of local characteristics based on transfer from the local L1(s)". The learner "aims only at easy intelligibility by native speakers rather than aiming to sound like a native speaker" (325). Cruttenden lists its phonological features in some detail (325-329). To the extent that its aim is intelligibility by native speakers, this target variety seems rather limited, for it is obvious that English is now widely and increasingly used as a Lingua Franca between speakers of other languages, to communicate in a wide variety of contexts - social, political, cultural, scientific, etc.

The other possible target variety is ELF. The only serious research into its phonological parameters is Jenkins (2000); for a summary of priorities and tolerances, see Cruttenden (2008:330-333). Jenkins studied communication between NNESs, focusing on details of pronunciation which are crucial in maintaining intelligibility. From this, she developed a Lingua Franca Core (Walker 2010:8): comprising 
- an approximation to most Received Pronunciation/General American consonants

- the appropriate treatment of consonant clusters

- length differences between vowels

- the placement of nuclear (sentence) stress

- (Weak forms, schwa, and other features of connected speech do not appear as core items).

Reactions to Jenkins' work have been mixed: Walker (2010:49-70) summarises both pros and cons. Particularly significant are fears of falling standards, loss of mutual intelligibility and lack of valid models. He argues, however, that ELF standards do exist, and that they are achievable, unlike the unrealistic standard of native-speaker pronunciation competence. As for intelligibility, he points out that there are huge variations even in native-speaker Englishes, but that despite this, communication succeeds, partly due to speakers' tolerance of variation ("people's extraordinary ability to make sense" [(Kirkpatrick 2007:167]). If speakers of ELF are taught to apply similar tolerance, then there should be no loss of intelligibility ${ }^{10}$. As for models, ELF empowers NNES teachers, who are the ideal models for their students. Summarising, Graddol (2006:87-88) considers that

ELF suggests a radical reappraisal of the way English is taught, and even if few adopt ELF in its entirety, some of its ideas are likely to influence mainstream teaching and assessment practices in the future.

Returning to the question of discourse features, Jenkins (2000:88) found, surprisingly, that the cause of every single breakdown in communication caused by pronunciation (rather than by lexis or syntax) was transfer of sounds from L1, rather than by the suprasegmental features favoured by communicative language teaching - "an almost complete reversal of

${ }^{10}$ Graddol (2006:87), however, points out that some NESs have poor language skills in international communication, and that "elements of an ELF syllabus could usefully be taught within a mother tongue [English] curriculum". 
current phonological orthodoxy" (135). That this was not found before may have been because previous research had concentrated on highly proficient speakers, who, she thinks, favour top-down processing of discourse features rather than the bottom-up processing employed by the lower-level learners she was studying, who are "heavily dependent on the acoustic signal - the actual sounds that they hear" (Walker 2010:27). Jenkins identifies four core areas where errors are crucial for understanding, nearly all of them segmental or syllabic, namely individual consonants, consonant clusters, vowels, and the placement of nuclear stress in an utterance. Interestingly, her research indicates that pitch movement, stress timing and word stress ${ }^{11}$ have little or no effect on intelligibility ${ }^{12}$. On the other hand, attempts to use features of connected speech (weak forms, elision, assimilation, etc. ${ }^{13}$ ), actually impede intelligibility in lower-level NNES interactions. This lack of importance given to intonation contrasts with the classic view, as expressed for example by Roach (2000:183), of the many layers of meaning that can be encoded in intonation - attitudinal, accentual, grammatical and discourse functions are all to be found in movements of pitch and variations in stress.

Where then does this leave us as English teachers? Are we to devote all our and our students' efforts to individual sounds, neglecting discourse features of pronunciation? The answer may lie in the levels we are teaching, as well as what we are teaching for. If our students are

11 Pitch movement: "In a piece of continuous speech, the speaker's voice can ... go up (a rise tone), or down (a fall tone), or do both [Walker 2010:200]. Stress timing: "the way that native speakers of English appear to 'squash' syllables together so that stressed syllables in the speech flow can come at more or less regular intervals" (Walker 2010:40). Word stress: "a characteristic and integral part of the phonemic identity of a word" (Underhill 2005:151). A stressed syllable usually sounds louder, higher-pitched or longer than unstressed sounds.

12 Word stress is "a grey area", as Jenkins acknowledges (2000:150), but one which she claims rarely causes miscommunication unless combined with another phonological error. Though miscommunication certainly did occur for the present writer, when during her first month in Portugal she asked in a small shop for a lambáda, and was puzzled by the reaction. What I needed (more than a punch) was a light bulb: so, a basic error in word stress (as well as in voicing and in vowel quality) certainly impeded communication at that point.

13 Elision: when a sound, present in an isolated word (as in the citation form in a dictionary) is absent in connected speech (e.g. /sænwit $\int /$ [sandwich]). Assimilation: sound changes under the influence of neighbouring phonemes (e.g. /døunt fo nэu/ [don't you know].) See Richards \& Schmidt (2010) for definitions of applied linguistic terminology. 
elementary, and are unlikely to use English for communicating with native or proficient non-native speakers (but how are we to know their future needs?), then a segmental focus is probably necessary. If, however, they need to progress beyond elementary or classroom English to something that meets social, educational and professional needs in the outside world, then such a limited focus will be inadequate.

Two personal examples may show this:

a. An English-speaking receptionist had a caller who wanted to speak to an employee of the company. She called the extension, and said "Is Susan there?", to which the reply, naturally, was "Who?". We can see that even a highly proficient speaker has not achieved control of prominence in nuclear (sentence) stress, and that this has impeded communication.

b. In another situation, a NNES hotel manager asked me if I ever teach my Portuguese students to "sound polite" in English, since she had trainees who regularly sound bored or even rude, in telephone and other service encounters, simply, it seems, because of the lack of pitch range in their intonation.

In the first case it is basic intelligibility that has been affected, whereas in the second, the speakers' intonation has led to misinterpretation of their attitude. In both cases, features beyond the segmental are obviously involved. And despite Jenkins' claim (2000:153) - "I do not believe that the use of 'native speaker' pitch movements matters very much for intelligibility among [non-bilingual English speakers]" - in this latter example it seems that they do matter crucially.

\section{Stressed about intonation? Some possible classroom approaches}

How are we as teachers to help our students to communicate effectively in English? What aspects of pronunciation should we focus on, and what can, or even should, be neglected? If our model is to be international English, rather than a local or a native-speaker variety, we need to look at what phonological features assist or impede communication between speakers of different L1s. 
As we have seen (section 4 above), Jenkins' work clearly identifies four elements, the first being individual sounds. While few teachers would dispute the importance of these in transmission of meaning, her research indicates areas where we can perhaps save time and effort. One of these is in the dental fricatives $/ \theta /$ and $/ ð /$, of which Walker (2010:30) remarks

\begin{abstract}
Absent from many of the world's languages, as well as from numerous native-speaker varieties of English, inherently difficult to pronounce, notoriously resistant to classroom teaching, and unnecessary to ELF intelligibility: it is not difficult to understand why the LFG [Lingua Franca Core] does not include the dental fricatives.
\end{abstract}

The plosive consonants $/ \mathrm{p} /, / \mathrm{b} /, / \mathrm{t} /, / \mathrm{d} /, / \mathrm{k} /$ and $/ \mathrm{g} /$ however, especially in initial position, are essential to 'get right' in ELF, since confusion could result from unclear articulation.

When clusters of consonants occur, there is more likely to be misunderstanding if consonants are omitted or elided, rather than if extraneous vowels are inserted (in the manner of some Italian or Japanese speakers), however 'non-native' this may sound. As for vowel sounds, there are so many variations even in native-speaker varieties that it seems unnecessary to go beyond a fairly simple distinction in quantity (length), though the quality of the sound cannot be totally ignored (Walker 2010:28-35). The remaining core ELF feature is the placement of nuclear stress,

the most important key to the speaker's intended meaning. (...) Contrastive stress is particularly important in English, since it does not have the morphological and syntactic resources that many other languages have to highlight contrasts (Jenkins 1997:18).

What is not considered important in ELF, but which we may well want to give time to in our classes, are intonation/ pitch, word stress and stress timing. While it is very hard to establish any particular grammatical significance for pitch (such as whether a rising tone is used for questions, etc.), the broader significance of pitch as an indicator of 
interest and involvement is clear (see section 3 above). Although there is wide individual variation in intonation, generally NESs tend to use a wider pitch range than many Portuguese speakers, for example. Timidity and unwillingness to sound foolish may restrict learners' range, and intonation is notoriously difficult for students to acquire, being considered 'unteachable' by some researchers (Walker 2010:39). But its effects are so important that it surely merits some serious effort in the classroom, which we shall consider below

Despite Jenkins' findings, my feeling is that learners need to know, or find out, which syllable of a word to stress. Rules on English word stress are difficult to establish, so it is best treated in vocabulary learning, as part of the information that students should gather when learning a new word; they will need to know how stress is marked in dictionaries, for example.

Stress timing is more problematic. The first problem is whether it actually exists: it is almost an article of faith for some teachers and materials writers, but firm evidence is hard to find. Nevertheless, according to Kelly (2000:71), it seems reasonable to think that English

has more of a tendency than some other languages to reduce vowel length and quality in unstressed syllables. ... Regularity of speech rhythm varies widely according to context, as it may bring in factors such as the relationship between the speakers, their confidence, nervousness, etc. and whether the speech is rehearsed or spontaneous ... Using language which is rhythmic and clearly patterned can, however, be very useful in the classroom, particularly for making students aware of the importance of stress (and intonation).

The fact that European Portuguese is also listed among stress-timed languages means that this aspect of pronunciation should not feel too foreign to our learners; work on stress-timing in class (see below), will help students to see phonological correspondences between the two languages, as well as to sound more fluent in their oral production.

The main feature of connected speech that has been indicated as actually impeding successful communication between NNES, is the replacement of 
vowels in unstressed syllables by schwa $(/ \mathrm{\partial} /)$ or other shortened vowels ${ }^{14}$. Even so, the fact remains that NNESs will meet such forms repeatedly in real life and in the media, and learners must be made aware of them through extensive listening practice if they are not to be at a loss in encounters with native speakers. It is not essential, however, that they be trained to produce them, except in the most commonly occurring words such as the articles /ðə/ and /ə/.

The rest of this section will examine a few ideas for classroom activities related to ELF in general, and, since I remain convinced of the vital importance of intonation and stress in the negotiation of meaning, I shall also include some suggestions on how these could be dealt with in class. I also want to consider briefly an aspect of particular interest to Portuguese teachers, namely the use of reading aloud in the classroom.

a. Despite ready access to a variety of Englishes on the internet, learners may benefit from a guided presentation by the teacher of a selection from a variety of comprehensible accents that exist in the world, so that they are not reduced to panic or laughter when exposed to non-GA or non-Portuguese English pronunciations. These should obviously be 'real people' speaking, not actors or - worse - teachers 'putting on' an accent, as has too often been the case with coursebook materials in the past. Walker's book (2000), for example, comes with a CD of useful material. Hewing's idea (2004:36) of 'impersonations', in which, after viewing (or listening to) a very brief extract from a well-known NES, students in pairs then try to imitate it, could usefully be extended to NNESs from different countries. Indeed, students could be encouraged to find and bring clips themselves, from which the teacher could select. (As Hewings points out, the idea is not to encourage students to use these varieties as permanent models, but rather to raise awareness of phonological differences and how these are physically produced). McKay (2002:127) recommends a cross-cultural approach from pragmatics, to foster interaction strategies that promote cooperation and mutual understanding, for example "deve-

${ }^{14} \mathrm{As}$ in table /'terbl/ and vegetable /'ved3tэbl/, or in board /'bo:d/ and cupboard /'knbэd/. 
loping ways to seek clarification, establish rapport, and minimize cultural differences - (...) to mutually seek ways to accommodate to diversity". Students should be encouraged to be successful listeners, those who "actively interrupt, seek clarification, and generally negotiate meaning with the help of the speaker" (Walker 2010:18).

b. Crucial to intonation and stress are word groups (also known as tone units): "small, meaningful blocks of words" (Walker 2010:201), often related to syntax and usually separated from each other by pauses. The stressed syllable (the nuclear stress) is normally in the last content word in the group, unless there is a word expressing a contrast or some other need to break the regular stress pattern - so, knowing where the regular stress should be helps the speaker's and listener's awareness of contrastive stress. In addition, the pauses help the listener by breaking the stream of speech into manageable chunks, and give time for processing the content. (Speakers, particularly young and nervous ones, may tend either to 'blurt out' a stream of words, or to hesitate and pause at semantically unhelpful points). Activities that alert the learner to these chunks of language, and thus to regular and irregular stress patterns, are therefore essential. Examples of such activities are dictation (Rimmer 1997), where the teacher reads a short text using natural word groups, which students mark in their text; the teacher then reads again, with students highlighting the stressed syllable in each word group. Groups of students could also record each other, and compare their versions with each other and with the teacher.

c. Activities highlighting contrastive stress include Kelly's idea (2000:78) of 'misunderstanding dialogues', short scripted role-plays requiring stressed words to clear up misunderstandings ("I'd like a big red cotton shirt". "Here you are - a big red cotton skirt". "No, I said ..." etc.). Matching statements are suggested by Walker (2010:87): a student reads a sentence and other students have to select the best implication: ("I LIKE their new flat" - "But I'm not in love with it" "I like THEIR new flat". - "It's a pity I don't like ours", etc.). Hewings (2004:144) also has an activity on 'hearing and saying prominent words', in which students listen and give the most appropriate reply. Underhill (2005:199) suggests that groups of students 
use a scripted dialogue, perhaps from their coursebook (preferably one that has a recording), and work on it, deciding which syllables to stress, where to pause, etc., then rehearse and perform (maybe record) it. They could then compare their version with a published performance.

d. Work on the communicative function of intonation can be quite playful (see, for example, Hancock 1995). To highlight the importance of pitch range, students (especially younger ones?) can pretend to be robots and speak in a flat, mechanical tone. Students can also try to express a particular mood through intonation, while others guess what mood is being conveyed. Nor does intonation need to be treated separately - like word stress (see above), the typical intonation contours of a lexical phrase can be presented along with the phrase as part of vocabulary learning (Setter \& Jenkins 2005:8).

e. An entertaining and pleasurably demanding way to deal with those features of intonation and stress that form part of the semi-mythical beast known as stress timing, is by means of chants (otherwise known as jazz chants or raps). Some of these are introduced, along with their many uses (not all phonological, though some focus on individual sounds as well as rhythm), by Graham (1978). They have the advantages of requiring learners to speak rhythmically and to practice lexical phrases in context; they can be adapted to individual, pair and whole class work, and they can be quite infectious and memorable, combining rhythm and repetition in a more pleasing way than the average drill. Though good examples are given in Graham's books, enterprising teachers can even write their own, though my advice is to keep it simple and never to forget what makes a chant special - the compelling rhythm.

f. Reading aloud by students is the pronunciation activity most favoured by Portuguese teachers in the present survey (section 2 above). Kelly (2000:81), however, points to the inherent difficulties of the technique: the often "stilted and unnatural" nature of the product, allied to the specific nature of the input ("written sentences are often longer than spoken ones, and more grammatically complex"). In addition, my impression is that while reading, many students are seduced by the appearance of the word on the page, producing sounds and syllables which they would 
not otherwise make. This does not imply that teachers should abandon reading, of course. But the slow and halting presentation of a page-long text from a coursebook in an unrehearsed reading by a few students to a large class, the teacher correcting a few isolated words and the reader continuing without even repeating (possibly without even hearing) those words - this can hardly be considered as pronunciation teaching or practice. Kelly (2000:82) suggests the kinds of short texts (personal accounts, short dramatic pieces, etc.) that are suitable for reading aloud, and the techniques that can usefully be employed (e.g. dividing texts so that all or at least a large part of the class can read). But above all, the teacher's reactions to unintelligible or halting pronunciation of words or word groups should be given more value. For example, the teacher herself, or (better) some members of the class, could note these instances and corrections, for more focused work by the whole class later. This is just another example of how focused listening can be integrated into pronunciation teaching.

\section{Conclusion}

In contrast with the views of certain writers on ELT, therefore, this study shows that many teachers in Portuguese state school classrooms do not need convincing of the value of pronunciation teaching. They also tend to agree with native-speaker teachers that prosodic features certainly do need attention, for reasons we have examined. In this they disagree with some proponents of the ELF model, who, as we have seen, give greater importance to the teaching of individual sounds. However, the techniques being used in some classrooms seem to present a restricted range of options, perhaps under the influence of those listed in the questionnaire - for, understandably, few respondents took the opportunity to add further information or additional techniques. It is unfortunate that available coursebooks and syllabuses tend to neglect pronunciation in general and prosodic features in particular, this being an area which teachers from both types of schools agree is important, which can only 
gain in importance with the wider use of speaking assessment in schools, and which will obviously repay creative attention and energy devoted to it in the classroom by both teachers and students.

The importance of listening within a framework of international communication, at all levels of learning, is stressed by Setter \& Jenkins (2005:13) who offer us a challenging conclusion:

The onus is on the teacher educator, teacher and students to learn to listen, both to themselves and to other speakers, and address features of their speech which may make it difficult for communication to take place. If we are going to use English as a world language, then let's use it for mutual understanding.

For despite all the doubts and difficulties we have examined above, we as teachers seem determined to continue in our efforts to help our students to communicate with the wider world, a world where comprehensible English pronunciation will be vital for the foreseeable future.

\section{References}

\subsection{Bibliography}

Brown, H. D. 2007. Principles of Second Language Learning and Teaching. New York: Pearson Education.

Celse-Murcia, M., D. M. Brinton \& J. M. Goodwin. 1996. Teaching Pronunciation: a Reference for Teachers of English to Speakers of Other Languages. New York: Cambridge U.P.

Collins, B. and I. M. MeEs. 2009. Practical Phonetics and Phonology. $2^{\text {nd }}$ ed. Abingdon, UK: Routledge.

CoOK, V. J. (Ed.). 2002. Portraits of the L2 User. Clevedon, UK: Multilingual Matters.

Cruttenden, A. (Ed.). 2008. Gimson's Pronunciation of English. $7^{\text {th }}$ ed. London: Hodder Education.

Dalton-Puffer., G. Kaltenboeck \& U. Smit. 1997. Learner attitudes and L2 pronunciation in Austria. World Englishes 16, 115-128. 
DANIELS, H. 1998. Psycholinguistic, psycho-social and procedural factors in the acquisition of authentic L2 pronunciation. In A. McLean. (Ed.). 1997. SIG Selections 1997 Special Interests in ELT, 80-85.

Graddol, D. 2006. English Next: Why Global English May Mean the End of English as a Foreign Language. London: British Council.

GraHAM, C. 1978. Jazz Chants; Rhythms of American English for Students of English as a Second Language. New York: Oxford U.P.

Hancock, M. 1995. Pronunciation Games. Cambridge: Cambridge U.P.

Hewings, M. 2004. Pronunciation Practice Activities: a Resource Book for Teaching English Pronunciation. Cambridge: Cambridge U.P.

JENkins, J. 2000. The Phonology of English as an International Language. Oxford: Oxford U.P.

JENKINS, J. 1997. Teaching English intonation for English as an international language: teachbility, learnability and intelligibility. Speak Out! 21, 15-25.

KACHRU, B. (Ed.). 1992. The Other Tongue: English Across Cultures. $2^{\text {nd }}$ ed. Urbana: University of Illinois Press.

Kelly, G. How to Teach Pronunciation. Harlow, UK: Pearson.

KIRKPATRICK, A. 2007. World Englishes: Implications for International Communication and English Language Teaching. Cambridge: Cambridge U.P.

Krashen, S. 1997. A conjecture on accent in a second language. In Z. Lengyel, J. Navracsics \& O. Simon. (Eds.). Applied Linguistic Studies in Central Europe, vol 1. Department of Applied Linguistics, University of Veszprem, Hungary.

Krashen, S. 1986. Bilingual Education and Second Language Education Theory. Sacramento, CA: California State Department of Education.

MCKAY, S.L. 2002. Teaching English as an International Language. Oxford: Oxford U.P.

RICHARDS, J. \& R. SCHMIDT. 2010. Longman Dictionary of Language Teaching and Applied Linguistics. $4^{\text {th }}$ ed. Harlow: Longman.

RIMmer, W. 1997. Dictation for teaching and testing pronunciation. Speak Out! 21, 36-38.

ROACH, P. English Phonetics and Phonology. Cambridge: Cambridge U.P.

Rogerson-Revell, P. 2011. English Phonology and Pronunciation Teaching. London: Continuum. 
SEIDlHOfER, B. 1999. Double standards: teacher education in the expanding circle. World Englishes 18, 233-245.

SETTER, J. and J. JENKInS. 2005. State-of-the-art review article. Language Teaching 3, 1-17.

Strevens, P. 1989. A 'dramatic' approach to improving the intelligibility of ITAs. English for Specific Purposes 8, 181-194.

Underhill, A. 2005. Sound Foundations: Learning and Teaching Pronunciation. $2^{\text {nd }}$ ed. Oxford: Macmillan.

WAlker, R. 2010. Teaching the Pronunciation of English as a Lingua Franca. Oxford: U.P.

Widdowson, H. G. 2003. Defining Issues in English Language Teaching. Oxford: Oxford U.P.

\subsection{Online references}

Gabinete de Avaliação Educacional, Ministério de Educação e Ciências, Portugal. Provas de Expressão Oral. Consulted 19/4/2012 at <http://www.gave.min-edu. $\mathrm{pt} / \mathrm{np} 3 / 10 . \mathrm{html}>$

Teaching Pronunciation, a Handbook for Teachers and Trainers: Three Frameworks for an Integrated Approach. 2001. Sydney: New South Wales Department of Education and Training. Consulted 11/6/2012 at <http://helenfraser.com.au/ downloads/ HF\%20Handbook.pdf>

Thornbury, S. 2010. P is for pronunciation. An $A-Z$ of ELT. Consulted 1/10/2011 at <http://scottthornbury.wordpress.com/2010/08/01/p-is-for-pronunciation/> 